\title{
СТОВПЕЦЬ ОЛЕКСАНДР,
}

кандидат філософських наук, докторант кафедри філософії,

соиіології та менеджменту соиіокультурної діяльності

Південноукрайнського національного педагогічного університету імені К. Д. Ушинського

\section{ПЕРЕОСМИСЛЕННЯ МОРАЛЬНО-ЕТИЧНИХ ТА ІНФОРМАЦІЙНИХ АСПЕКТІВ ЖИТТЯ СОЦІУМУ У ФІЛОСОФСЬКОМУ ДОСЛІДЖЕННІ ІНСТИТУТУ ІНТЕЛЕКТУАЛЬНОЇ ВЛАСНОСТІ}

У статті аналізуються чотири сфери соціального буття - т. зв. "інформаційна сила", суспільна мораль, публічна інформація й масова інформація. Стверджується, що всі вони в інформаційно залежному суспільстві $є$ доволі тісно пов'язаними, а осмислення їхніх взаємних кореляцій і детермінацій $є$ важливою справою на шляху дослідження інтелектуальної власності як одного 3 фундаментальних соціальних інститутів сучасності. Розуміння інформаційної та етичної природи інтелектуальної власності надає можливість скласти більш об'єктивне уявлення про характер трансформації цього різновиду власності в нинішніх соціокультурних реаліях.

Ключові слова: інтелектуальна власність; інформація; суспільна мораль; інформаційна залежність; суспільство.

Постановка проблеми. Тема інтелектуальної власності значно ширша, ніж це може видаватися на перший погляд. Вона, зрозуміло, не обмежується тільки правовими питаннями. Більше того, останні взагалі не можна вважати самодостатніми, адже право - це прикладний інструмент, й окремо від усього спектра проблем - соціально-економічних, культурних, політичних, інших - право не мало б жодного сенсу у сфері відносин інтелектуальної власності. Також, на наш погляд, було б некоректно стверджувати, що проблематика інтелектуальної власності може бути цілковито й вичерпно розкрита в площині антиконтрафактної політики, чи в рамках руху за "вільну культуру" та "відкритий контент", чи в будь-якій іншій окремій сфері. Прагнення вийти за межі "класичних координат" інтелектуальної власності й обумовлює актуальність нашого дослідження.

Аналіз останніх наукових досліджень і публікацій з окресленої проблематики свідчить про те, що висвітлення юридичних питань доступу громадськості до публічної інфооммації, а також аналіз правових відносин у царині інформаційних процесів започатковано в роботах В. Іванова, Ю. Корзунова, А. Марущака, Т. Третяка, О. Яременка та деяких інших дослідників. Проблема ж "інформаційної сили" стала, головним чином, предметом ґрунтовного вивчення Д. Найя [3] (який також застосовував термін "м'яка сила" наряду із зазначеним вище). Інший дослідник - Д. Роткопф - вивчає природу "інформаційної сили" в контексті становлення кіберполітики [6]. Наша ж мета - синтезувати соціально-фрілософське бачення взаємної детермінації та кореляції зазначених у назві статті аспектів сучасного життя 3 відповідною екстраполяцією цих зв'язків та взаємозалежностей на такий соціальний інститут, як інтелектуальна власність.
Виклад основного матеріалу. Інтелектуальна власність - цілий комплекс міждисциплінарних, міжгалузевих, інтерсоціальних зв'язків, що залучають до свого простору і проблему творчості та інновацій; і питання щодо свободи інформаційного обміну; і економічні й технологічні аспекти функціонування інфраструктури (у т. ч. правової) інфрормаційно-залежного суспільства; i ментально-психологічні, ідеологічні контроверсії в ставленні до феномену інтелектуальної власності та всієї множинності його проявів у різні історичні епохи; і питання правової охорони та захисту об'єктів творчості; i гуманітарні аспекти інтелектуальної діяльності... Цей ряд можна було б продовжувати ще.

У цій статті бачиться доцільним зосередитися на двох групах аспектів життя соціуму - морально-етичних та інформаційних - які істотно впливають на фрормування закономірностей розвитку інституту інтелектуальної власності. До таких морально-етичних аспектів належить категорія "суспільна мораль", а також феномен "інформаційної сили" (останній займає проміжне положення в системі морально-етичних та інформаційних кореляцій). Серед розмаїття інформаційних аспектів сучасного життя найбільш актуальними в дослідженні протиріч інтелектуально-правової сфери бачаться феномени "публічної" й "масової інформації", їхні взаємні детермінації та зв'язок з інститутом інтелектуальної власності.

Розглядаючи феномен інформаційної сили, маємо зауважити, що ми виходимо з того методологічно важливого положення, відповідно до якого відносини у сфрері інтелектуальної власності є особливим різновидом інфрормаційних відносин. Подібне твердження знайшло обґрунтування в іншій роботі автора статті [1]. Однак не кожен суб'єкт інформаційних відносин здатний ефектив- 
но використовувати "інтелектуальний капітал" як усередині своєї країни, так і в міжнародних справах.

Інформація існує у світових комунікативних процесах як об'єктивна реальність і проявляється у двох іманентних формах: як сукупність індивідуальних характеристик кожного суб'єкта (осіб, держав та їхніх альянсів, міжнародних організацій, у нашому випадку таких як Всесвітня організація інтелектуальної власності) - "інфоструктура" і як віддзеркалення взаємодій цих суб'єктів у комунікативному середовищі - "інфопотоки" [2]. У процесі комунікації сторони справляють одна на одну інформаційний вплив, який у концепції Д. Найя одержав визначення "інформаційної сили" (англ. information power) [3].

Аналіз сутності "інформаційної сили" розкриває глибокий дуалізм досліджуваного феномену. 3 позиції інформаційно-кібернетичного підходу, заснованого на роботах К. Дойча [4], інформаційна сила з'являється в якості нескінченного, але керованого потоку інформаційних ресурсів у сорері глобальної політики й міжнародних відносин. Якщо ж спиратися на комунікативний підхід Ю. Габермаса [5], то інформаційна сила визначається як сукупність зв'язків і відносин, що формуються навколо встановлених інфопотоків, пов'язаних із розв'язанням певних політичних завдань, у тому числі й глобальних проблем.

Опоненти Д. Найя схильні вважати, що інформаційна сила стала можливою завдяки зростанню жорсткої залежності суб'єктів міжнародних відносин від автоматизованих інфрормаційно-комунікаційних систем. Присутність фрактора "інформаційної сили" призводить до децентралізації державної влади, дезінтеграції суспільства, прискорення індивідуального розвитку, віртуалізації життя, до асиметричної динаміки в розвитку економічної, культурної й політичної складових соціуму, а також до еволюції в засобах захисту національної безпеки [6; 7]. Можливо, інформаційна сила є одним із тих фракторів, що сприяють підсиленню інституційного нігілізму, коли жорстка інституційна ієрархія попередніх часів поступово розхитується, стає гнучкішою. Цей процес можна віднести до постмодерних тенденцій.

У площині інтелектуально-правових відносин концепція "інформаційної сили" реалізується в повному спектрі - починаючи від здійснення (за ініціативою окремих країн) повсюдного інтенсивного моніторингу ситуації з інтелектуальною власністю силами спеціально створених органів (наприклад, американським урядовим агентством USTR), до явного лобіювання глобального впровадження більш жорстких антиконтрафрактних законів, виконання яких може підтримуватись різними санкціями. Звісно ж, такі санкції у відношенні порушників "копірайту" зазвичай інспіруються найбільш впливовими країнами-інноваторами, які одночасно і $\epsilon$ суб'єктами, що концентрують у своїх руках "інформаційну силу" й тримають головні важелі її вибіркового застосування - санкції (різного роду обмеження, блокади, бойкоти, мораторії, штрафи, тощо).

В інтелектуально-правовій сфері значна "інформаційна сила" належить найбільшим лобістам "копірайту" - софтверним компаніям, власникам найвідоміших світових брендів, організаціям колективного управління авторськими правами, іншим корпоративним суб'єктам. У цьому зв'язку треба відзначити, що американське урядове агентство USTR (United States Trade Representative, Торгове представництво США) щороку складає звіт зі списком найбільш злісних порушників копірайту у світі. Точніше, списків таких три. Окремо ведуться списки країн, сайтів та найбільших у світі офрлайнових ринків, де відкрито продається контрафакт. Зга- даний документ має назву "Список 301" (Special 301 Report), тобто Спеціальний звіт 301 за відповідний рік. Уважається, що країни, котрі регулярно потрапляють до нього, не забезпечують адекватної та ефективної правової охорони інтелектуальної власності. Списки ці щорічно направляються до Адміністрації Президента США й до американських посольств, щоб ті на вищому рівні забезпечили дипломатичний тиск на владу провинених країн.

В усіх минулорічних звітах USTR з 2012 року такі країни, як Китай, Індія, Україна, Росія, Аргентина, Чилі, Еквадор, Індонезія та деякі інші стабільно потрапляють у Priority Watch List - список за категорією "головні порушники копірайту у світі". Серед популярних в Україні вебресурсів найчастіше у звітах Торгового представництва США згадувалися "The Pirate Bay", "Rutracker", "Вконтакте", "Warez-bb", "EX.ua", а серед звичайних ринків, де поширюється контрафакт, - "Петрівка" у Києві, "7-й кілометр" в Одесі.

В звіті USTR за 2015 рік навіть міститься примітка, що у 2013 і 2014 р. Україну було віднесено до особливої категорії - Priority Foreign Country (PFC). Власне про Україну сказано таке: "Україна залишається у Priority Watch List y 2015 році. Одразу три фрактори дають підстави для віднесення України до категорії PFC: (1) недоброчесне й непрозоре адміністрування системи товариств, що мають відповідати за збір та розподіл роялті, належних правовласникам у США та інших країнах; (2) широке застосування й неприховане використання нелегального програмного забезпечення (софту) навіть серед державних установ України; (3) відсутність прогресу в запровадженні ефрективних засобів для боротьби з украй поширеним онлайн-порушенням авторських і суміжних прав в Україні, у тому числі відсутність прозорої та системної концепції стосовно відповідальності на посередницькому рівні - провайдерів і третіх осіб, які полегшують піратство, зокрема, шляхом недотримання ними обов'язків щодо повідомлення про порушення онлайн-контенту". Разом із тим, у звіті рекомендується не вживати зараз санкційних заходів щодо України у зв'язку з недотриманням стандартів охорони копірайту, "...враховуючи ту кризову політичну ситуацію, що нині склалася в країні" [8, с. 55].

3 іншого боку, ураховуючи неоднорідність людства й розмаїття суспільств, що історично склалися на планеті, та зважаючи на інтенсивну динаміку інформаційного розвитку людства й суперечливість національних інтересів, можна констатувати, що в сучасному світі співіснують різні ідеології щодо перспектив розвитку інституту інтелектуальної власності. Що ж стосується практики використання "інформаційної сили" окремими суб'єктами комунікативного процесу, то варто розуміти, що однобічне її застосування, навіть коли йдеться про порушення права інтелектуальної власності, тим не менш, не сприяє зменшенню конфрліктності. Сам правовий інститут інтелектуальної власності - у багатьох аспектах застарілий, негнучкий і в цілому недостатньо адекватний сучасним інформаційним реаліям - $\epsilon$ певною мірою генератором правопорушень у досліджуваній сфері суспільних відносин. Тому сподівання світових лідерів на одну тільки "інформаційну силу" та занадто часте ї̈ застосування не дає очікуваних результатів.

Проблематика "інформаційної сили" та правомірності її використання логічно підводить нас до необхідності аналізу ще однієї етичної категорії, яка має пряме відношення до проблем інтелектуальної власності, доволі неоднозначної категорії "суспільна мораль". Перш за все, звернемося, власне, до законодавства 
України, у якому суспільну мораль визначено як систему етичних норм, правил поведінки, що склалися в суспільстві на основі традиційних духовних і культурних цінностей, уявлень про добро, честь, гідність, громадський обов'язок, совість, справедливість [9, ст. 1]. Проте існує чимало альтернативних дефініцій досліджуваної категорії.

Очевидно, що в регулюванні суспільних відносин мораль і право обумовлюють, доповнюють та забезпечують одне одного. Однак у науковому середовищі співіснують різні погляди стосовно співвідношення цих фундаментальних складових та їхнього функціонального навантаження в механізмі суспільної самоорганізації. Так, окремі фрілософи розглядають право як "мінімальну дефініцію моральності", як "юридично оформлену мораль", як "примусову вимогу здійснення мінімального добра та порядку, що не допустить відвертого прояву зла" [10; 11]. Інші дослідники [12] акцентують увагу на тому, що, крім моментів, які визначають єдність права й моралі, це співвідношення містить у собі також ще один надзвичайно істотний аспект - їхнє протиріччя. Воно, зокрема, стосується генези, змісту, мотивацій та засобів забезпечення.

Іншими словами, причини діалектичних протиріч між правом і суспільною мораллю полягають у специфіці цих соціальних інститутів, у різних методах регуляції, в особливостях підходів та застосовуваних аксіологічних критеріїв. Так, з юридичної точки зору, правомірність виключної монополії на певний результат інтелектуальної, творчої діяльності у спадкоємців автора не викликає жодного сумніву. Однак з погляду суспільної моралі володіння правом інтелектуальної власності не-автором (особливо, якщо спадкоємець автора взагалі немає ніякого іншого відношення до твору, окрім, зрозуміло, родинних зв'язків з автором або ж приватноправових стосунків) нерідко викликає суспільне нерозуміння, супроводжуване вимогами щодо скорочення строків цієї монополії або ж повного іiі скасування.

Слід зауважити й дещо інший момент: інтелектуальна власність (як і будь-яка власність) - зобов'язує. Об'єкти права інтелектуальної власності недопустимо використовувати на шкоду суспільству або окремим індивідам. Отже, якщо творча продукція, незважаючи на її інтелектуально-правову природу, за своїм змістом або формами зовнішнього прояву ігнорує норми суспільної моралі, прийнятні для певного соціуму, то цілком обґрунтовано, коли розповсюдження такої продукції може бути, за рішенням компетентних державних інституцій, обмеженим або ж узагалі забороненим.

Поринаючи в роздуми стосовно доступності інформації в Інтернеті, мабуть, також не можна сказати однозначно, чи потрібно з міркувань захисту суспільної моралі обмежувати доступ дітей до таких ресурсів, як, наприклад, "Wikipedia". 3 одного боку, це істотне та універсальне джерело різноманітних популяризованих знань (до того ж, на безоплатних умовах і без усякої реклами). 3 іншого боку, ніщо не заважає допитливій дитині знайти у "Вікіпедії" детальне (інколи ще й ілюстроване) описання всіляких парафілій, перверсій та девіацій. I невідомо, який вплив справить подібна інформація на дитячу психіку. Отже, як і будь-яке благо, навіть "культурний" сегмент Інтернету має свій зворотній бік. Водночас, у світовій культурно-історичній скарбниці можна знайти зображення подібних парафілій: так, барельєфи та інший скульптурний декор всесвітньо відомих храмів Кхаджурахо в індійському штаті Мадх'яПрадеш, створених понад тисячоліття тому правителями з династії Чандела, серед іншого, містять і згадувані мотиви, однак їхнє споглядання зазвичай не вважається аморальним.

Калейдоскоп поглядів та переконань стосовно проблеми суспільної моралі, дуже вдало охарактеризував, на нашу думку, М. Вебер: у вільному суспільстві виявляється, що єдиної загальноприйнятої моралі не існує - моральні проблеми можуть мати більш ніж один правильний варіант вирішення. Тому соціально-філософську і правову дискусію на цю тему можна продовжувати нескінченно, поширюючи її доводи на різні сфери суспільного буття, у т. ч. і на інтелектуальну власність.

Амбівалентність інтелектуальної власності, можливість її об'єктів одночасно містити як приватноправові, так і публічноправові аспекти, створює потребу дослідити ще одну важливу категорію - публічну інформацію, що знайшла нормативну фіксацію в Законі України "Про доступ до публічної інформації" [13]. Звісно, у згаданому законі нічого не сказано стосовно того, яким $€$ співвідношення понять "публічна інформація" і "загальносуспільне надбання". Розуміння їх зв'язку важливе для нас у контексті досліджуваної інтелектуально-правової проблематики.

Аналізуючи особливості правового режиму публічної інформації та її місце в загальній структурі суспільних відносин, необхідно виходити з того, що право на доступ до інформації є одним із ключових інститутів не тільки інформаційного права, а ще й конституційного та цивільного (а в системі останнього й розвивається підгалузь права інтелектуальної власності). Воно сформувалося в результаті еволюції прав людини, першооснову яких тривалий час становила свобода слова. Такий підхід було започатковано в Загальній декларації прав людини (1948), яка передбачає, що кожна людина має право шукати, одержувати й поширювати інформацію та ідеї будь-якими засобами і незалежно від державних кордонів [14, ст. 19]. Однак зазначений міжнародний акт закріпив загальне право на доступ до інформації як такої, не конкретизуючи іï видів. Між тим, активний розвиток інформаційної сфери потребував більш чіткого юридичного розмежування і встановлення різних правових режимів для окремих видів інформації. Людство еволюціонує, тому закономірно, що на певному історичному етапі розвитку інформаційних відносин знадобилося виокремити із загального "права на інформацію" право на доступ до окремих її різновидів.

У процесі дослідження зв'язку категорій "публічна інформація" й "інтелектуальна власність" стає зрозуміло, що будь-які результати інтелектуальної діяльності суб'єктів, котрі в більшості випадків генерують інфрормацію, яку законом віднесено до "публічної", в силу загальносуспільного призначення не підпадають під поняття інтелектуальної власності у повному розумінні. Тобто не виникає жодних виняткових майнових прав на подібні інтелектуальні результати. Водночас, безумовно, можна вести мову про автоматичне виникнення немайнових прав (перш за все, права авторства), що, утім, не передбачає якихось монополій або ж пріоритетів на доступ до інформації, якщо таку інформацію не було віднесено законодавством до спеціальних категорій (службової, таємної, конфіденційної).

Нарешті, останнім аспектом, що вивчається в рамках цього дослідження, є питання про співвідношення публічної та масової інформації. 3 одного боку, будьяке суспільство має потребу захищати свій інформаційний простір і дбати про збереження конфіденційності відомостей, що становлять винятковий національний інтерес. 3 огляду на це, доступ до таких відомостей має бути обмеженим або взагалі закритим від пере- 
важної більшості людей, у тому числі, від власних громадян. Разом із тим, виникає ряд неоднозначних питань щодо існуючих концепцій розповсюдження інформації. Нові технологічні реалії (зокрема, ті досягнення IT, що спрямовані на забезпечення віртуальної анонімності, або ж навпаки - на оприлюднення закритої інформації) підтримують перманентну актуальність такої тематики.

Як відомо, виникнення Інтернету зламало державну інформаційну монополію, навіть т. зв. "Велика китайська інформаційна стіна", або "Великий китайський брандмауер" (англ. Great Firewall of China), не дозволяє здійснювати КНР абсолютний контроль свого інформаційного простору, адже є Tor. Так, дійсно, близько 80 \% IP-адрес публічних серверів Tor у КНР було включено до "чорного списку" [15] загальнодержавного китайського проекту The Golden Shield Project (金盾工程). Однак залишаються ще 20 \%, державою не контрольованих, і прибічники віртуальної анонімності теж не сидять, склавши руки.

Саме існування та особливості функціонування мережі Tor $є$ дуже цікавими для розуміння проблем сучасності, в оточенні яких і розвивається інститут інтелектуальної власності. Tor (скор. від англ. The Onion Router) - це вільне та відкрите програмне забезпечення для реалізації так званої "цибулевої маршрутизації". Tor $€$ системою проксі-серверів, яка дозволяє встановлювати анонімне мережеве з'єднання, захищене від прослуховування, перегляду або інших форм доступу сторонніх осіб (включаючи й державні спецслужби). Іншими словами, Tor можна розглядати як анонімну мережу віртуальних тунелів, по яких передавання даних здійснюється в зашифрованому вигляді. Якщо зазвичай інтернет-користувач застосовує для проведення своїх операцій (наприклад, для банківських платежів, або для покупок в інтернет-магазинах, або просто для інтернет-броузингу) стандартні проксі-сервери, то для звичайного провайдера $є$ доступною інформація і про те, хто є користувач (адже він ідентифікується за IPадресою), і про те, що він шукає в Інтернеті. Будь-який провайдер бачить зміст трафіку користувача, оскільки цей трафік проходить через проксі-сервер. В окремих випадках провайдери навіть можуть побачити інсайдерський зашифрований трафік своїх клієнтів у процесі посередництва в трансляції користувацької інформації на сайт відповідного банку або платіжної системи, або на сайт електронної торгівлі. Користувачеві лише залишається просто вірити, що провайдер не буде нишпорити в доступній йому інформації клієнта, зокрема, не буде інфільтрувати власну рекламу в його трафіковий потік, і не буде записувати персональні дані клієнта [16].

За допомогою Tor користувачі можуть зберігати анонімність в Інтернеті при відвідуванні сайтів, веденні блогів, відправленні миттєвих і поштових повідомлень, при здійсненні розрахунків у криптовалюті Bitcoin за допомогою електронних гаманців, а також при роботі з іншими додатками, що використовують інтернет-протокол TCP (Transmission Control Protocol). Анонімізація трафіку забезпечується за рахунок використання розподіленої мережі серверів - різноманітних вузлів (вхідних, посередницьких, вихідних, сторожових, мостових тощо). Технологія Tor також забезпечує захист від механізмів аналізу трафіка, котрі ставлять під загрозу не тільки принцип приватності у Всесвітній мережі як такий, але й конфіденційність конкретних комерційних таємниць, особистих ділових контактів і таємницю зв'язку в цілому. Тому деякі користувачі використовують можливості Tor для захисту недоторканості приватного жит- тя та з метою отримання доступу до інформації, заблокованої інтернет-цензурою у "звичайному" сегменті віртуального простору.

Використання анонімної мережі Tor нерідко $є$ доволі виправданим, особливо з огляду на повсюдну тенденцію до посилення контролю інтернет-простору. Тоталітарні посування спостерігаються не тільки в традиційно "нелояльних до Інтернету" Китаї, Ірані, Туреччині та ряді інших країн. Вони стають реальністю навіть у таких (як прийнято вважати) демократичних країнах, як США та Великобританія. Королева останньої в листопаді 2016 р. підписала вкрай суперечливий закон "Про повноваження слідства" (The Investigatory Powers Act, IP Act). Цей закон зобов'язує інтернет-провайдерів та операторів мобільного зв'язку не видаляти інфрормацію про активність абонентів за останні 12 місяців. Зокрема передбачається, що протягом року мають зберігатися відомості про телефонні дзвінки британців і відвідувані ними веб-сайти. Доступ до такої інформації отримають урядові організації й спецслужби. При цьому ордер для подібних дій знадобиться їм тільки в окремих випадках. Ідеться про ситуації, коли поліція, наприклад, вимагатиме розкрити джерело інформації журналістів. Крім цього, до повноважень британських правоохоронців увійде і прямий "злам" комп'ютерних систем і мобільних гаджетів громадян. Однак для таких заходів вже буде потрібний спеціальний ордер, який видаватиме орган, що складатиметься з призначеного урядом комісара і колегії суддів [17].

Раніше повідомлялося про ухвалену (наприкінці 2015 року) угоду між Євросоюзом і США під назвою "Персональний щит", яка дозволяє зберігати інформацію європейських громадян на американських серверах. Це сталося після того, як у жовтні 2015 р. Європейський суд у Люксембурзі визнав недійсним укладений у 2000 р. між ЄС і США договір під умовною назвою "Безпечна гавань". І ось тепер парламент Великобританії прийняв закон "Про повноваження слідства", що наділяє спецслужби і правоохоронні органи безпрецедентно широкими можливостями щодо стеження за мільйонами підданих Сполученого Королівства, збирання даних щодо їхньої активності "оптом" і без якихось істотних фактичних підстав для цього. Д. Кіллок, керівник Open Rights Group - некомерційної організації, що займається питаннями дотримання прав людини в цифровому просторі, захисту інтелектуальної власності та протидії цензурі в Інтернеті, - охарактеризував новий закон як один із найбільш екстремальних нормативних актів щодо спостереження, що будь-коли був прийнятий у "світі демократії". Закон цей матиме, на його думку, вплив, що виходитиме далеко за межі берегів Великобританії. Інші правозахисники вже прозвали The IP Act "смертельним вироком для журналістських розслідувань у Британії", адже він стосується і розкриття таємних інформаторів.

Зазначений закон, також відомий як "Хартія сищиків" (Snooper's charter), дійсно може стати одним із найжорсткіших законів щодо стеження за власними громадянами в новітній практиці західних держав. Законопроект спочатку був представлений міністром Т. Мей у листопаді 2015 року, коли вона ще займала посаду глави МВС Британії. Однак ця ініціатива тоді провалилася. Прийняти документ вдалося лише після т. зв. "Брекзіту", коли Т. Мей очолила уряд Сполученого Королівства. Єлизавета II закон підписала, тому він має набути чинності вже наприкінці грудня 2016, коли припиняє свою дію прийнятий в 2014 році Data Retention and Investigatory Powers Act [18].

Ось і відповідь, чому анонімні мережі стають все 
більш популярними та затребуваними в інформаційно залежному суспільстві. Приховані сервіси Tor надають своїм користувачам можливість створювати власні вебсайти й електронні 3MI, не розкриваючи при цьому інформацію про їхнє реальне місцерозташування, не видаючи своїх таємних інформаторів тощо. Саме такими сервісами активно користуються у своїй діяльності WikiLeaks, Anonymous, інші суб'єкти інформаційних відносин, що працюють на анонімних началах.

$€$ й оборотна сторона функціонування мережі Tor можливість використання ії в злочинних цілях. Це й торгівля наркотиками, і розповсюдження дитячої порнографії, і здійснення кібер-диверсій проти окремих установ і національної безпеки в цілому. Наприклад, у 2007 році Національна поліція Швеції заарештувала відомого експерта з комп'ютерної безпеки Д. Егерстада за обвинуваченням у неправомірному доступі до комп'ютерної інформації. Він, будучи працівником компанії Deranged Security, опублікував на своєму робочому сайті паролі до електронної пошти посольств, неурядових організацій, комерційних компаній і державних агенств різних країн. Як пояснив обвинувачуваний, в якості експерименту він створив декілька вихідних серверів Tor і перехоплював через них незашифрований трафік. У результаті Д. Егерстаду вдалося заволодіти паролями до близько 1000 облікових записів, що належали дипломатам, зокрема, працівникам російського посольства у Швеції, а також співробітникам дипмісій Казахстану, Індії, Узбекистану, Ірану, Монголії, Гонконгу, Японії, директорові індійської Організації оборонних досліджень, а також британському представництву в Непалі [19].

Про нові можливості безкарного порушення прав інтелектуальної власності з використанням Tor годі й говорити. Це очевидно. Тому знов-таки доводиться констатувати дуальність інформаційних технологій: вони можуть бути і осередком зла, і джерелом блага; здатні як посилювати протиправні тенденції, так і нести звільнення од тоталітарної цензури. Імовірно, ми ще неодноразово повертатимемося до роздумів про діалектику інформації та протиріччя сучасного інформаційно-залежного світу, адже ця тематика є дуже реалістичною й актуальною. Інформаційні та моральноетичні чинники здатні змінювати масову ідеологію, що позначається на розвитку інституту інтелектуальної власності. На цьому мусимо перервати зазначені роздуми й дещо резюмувати викладений вище матеріал.

\section{Висновки}

У рамках статті було досліджено чотири сфери соціального буття - т. зв. "інформаційну силу", суспільну мораль, публічну інформацію та масову інформацію. На перший погляд, зв'язок цих категорій між собою і їхнє відношення до інституту інтелектуальної власності $€$ не зовсім очевидними. Проте всі вони в інфрормаційно залежному суспільстві $€$ доволі тісно пов'язаними, а осмислення їхніх взаємних кореляцій і детермінацій $є$ важливою справою на шляху дослідження інтелектуальної власності як одного з фундаментальних соціальних інститутів сучасності. До того ж розуміння інформаційної та етичної природи інтелектуальної власності надає можливість скласти більш об'єктивне уявлення про характер трансформації такого різновиду власності в нинішніх соціокультурних реаліях.

Феномен "інфрормаційної сили" пов'язаний з інститутом інтелектуальної власності функціонально: країни-інноватори докладають максимальних організаційних (політичних, юридичних) і технологічних зусиль, щоб якомога довше зберігати монополію на продукцію інте- лектуальної власності. У першу чергу це стосується тих об'єктів, що охороняються правом промислової власності (тобто захищених патентами), і об'єктів копірайту (на твори літератури, програмне забезпечення, іншу "інтелектуально містку" продукцію). Від ефективності захисту цієї монополії залежить перспектива домінування відповідних країн у постіндустріальному світі. Інколи застосування "інформаційної сили" ігнорує принципи суспільної моралі, ідучи у розріз із ідеями гуманізму, рівності, свободи інформаційного обміну, вільного доступу до знань і технологій та деякими іншими шляхетними постулатами, про відданість яким регулярно заявляється урядами провідних країн та ліберальним співтовариством.

Інститут суспільної моралі, у свою чергу, має важливе значення для обґрунтування інтелектуальної власності, для легітимізації цього різновиду "монополії на знання" в інформаційно залежному суспільстві. Від стану суспільної моралі залежить формування ідеології різних суспільств, а також ментальні прояви їхнього ставлення до власності як такої та інтелектуальної власності зокрема.

Публічна інфрормація - це доволі містке поняття. У контексті інтелектуальної власності воно найбільш застосовне до випадків, коли термін дії інтелектуальноправової монополії спливає і відповідний продукт творчості, інтелектуальної праці переходить у категорію загальносуспільного надбання. Якщо обмежуватися термінологією інформаційного законодавства України, тоді можна зробити висновок, що такий різновид інфоормації, як публічна майже несумісний із будь-якими монополіями на інформацію; а отже, право на поширення "інформації, що є предметом суспільного інтересу" (тобто публічної інформації) вступає в логічне протистояння із правом інтелектуальної власності. I надалі все залежатиме вже від фрілософрської інтерпретації, адже будь-який інтелектуальний продукт має свою користь для потенціалу суспільства, відповідно, і будь-який об'єкт права інтелектуальної власності може апріорі розглядатися в якості такого, що $є$ "предметом суспільного інтересу". Однак тут можна згадати про конституційні принципи недоторканості приватної власності, та поваги до виняткового права автора володіти, користуватися й розпоряджатися результатами власної інтелектуальної, творчої праці. Урешті-решт, будь-яку працю має бути справедливо винагороджено, а інтелектуальну - особливо.

Термін "масова інформація", на відміну від "публічної", не стільки має відношення до змістовного наповнення, скільки до аудиторії, на яку розраховане ії поширення (на необмежене коло осіб), та до засобів i способів ретрансляції (за допомогою різноманітних 3МІ). Суспільна значущість масової інсоормації теж варіюється, вже залежно від ії змісту. Інститут інтелектуальної власності "зустрічається" з інститутом масової інформації в комунікативному просторі, засоби масової інфрормації здатні вельми ефективно сприяти комерціалізації інтелектуальної власності. ЗМІ часто виконують популяризаторську, дистрибутивну функцію щодо новостворених об'єктів права інтелектуальної власності; останні ж, у свою чергу, справлять безпосередній вплив на рейтинговість ЗМІ, наповнюючи їхні ефіри та сторінки різноманітною творчою продукцією, яка знаходить свою аудиторію.

\section{ЛІЕРАТУРА}

1. Стовпець О. В. Онтологічні засади інтелектуальної власності / О. В. Стовпець // Наукове пізнання: методологія та технологія. - 2015. - № 1 (34). - С. 179-186. 
2. Зобнин А. В. Пространство и время в мировой политике и международных отношениях / А. В. Зобнин // Материалы 4-го Конвента РАМИ : в 10 т. / [под ред. А. Ю. Мельвиля] ; Российская ассоциация международных исследований. - М. МГИМО-Университет, 2007. - Т. 6: Новые тенденции в мировой политике / [под. ред. В. С. Ягья, В. С. Денисенко]. - 152 с.

3. Nye J. S. Soft Power: The means to success in world politics / Joseph S. Nye. - New York : Public Affairs, 2004. - 191 p

4. Deutsch K. W. Nationalism and Social Communication: An Inquiry into the Foundations of Nationality. - Cambridge (Massachusetts) : MIT Press, 1966. - 345 p.

5. Хабермас Ю. Моральное сознание и коммуникативное действие / Ю. Хабермас ; [пер. с нем. под ред. Д. В. Скляднева]. - СПб. : Наука, 2000. - 380 с.

6. Rothkopf D. J. Cyberpolitik: The Changing Nature of Power in the Information Age / D. J. Rothkopf // Journal of International Affairs. - Spring 1998. - Vol. 51. No. 2. - Pp. 325-359.

7. Libicki M. C. Information War, Information Peace / M. C. Libicki // Journal of International Affairs. - Spring 1998. - Vol. 51. No. 2. P. 411-428

8. Froman M. 2015 Special 301 Report [Електронний ресурс] / Ambassador Michael B. G. Froman, United States Trade Representative // Executive Office of the President of the United States. - 78 р. - Режим доступу : https://ustr.gov/sites/default/ files/2015-Special-301-Report-FINAL.pdf.

9. Про захист суспільної моралі: Закон України від 20 листопада 2003 р. № 1296-IV // ВВР України. - 2004. - № 14. Ст. 192 (у чинній поточній редакції від 09.12.2015).

10. Соловьёв В. С. Оправдание добра. Нравственная философия / В. С. Соловьев // Собр. соч. : в 2 т. - Т. 1. - М. Мысль, 1988. - 479 с.

11. Ильин И. А. О сущности правосознания / И. А. Ильин // Собр. соч. : в 10 т. - Т. 4. - М. : Русская книга, 1994. - 498 с.
12. Дрожжина С. В. Проблема взаємодії права і моралі як ціннісних регуляторів суспільних відносин у контексті соціально-фрілософського дискурсу / С. В. Дрожжина, І. В. Ширкова // Гілея: науковий вісник : зб. наук. пр. (Філософські науки) / [гол. ред. В. М. Вашкевич]. - К. : ВІР УАН, 2011. - Вип. 47(5). 792 c.

13. Про доступ до публічної інформації: Закон України від 13 січня 2011 р. № 2939-VI // ВВР України. - 2011. - № 32. Ст. 314 (у чинній поточній редакції від 01.05.2015).

14. Загальна декларація ООН з прав людини 1948 р. [Електронний ресурс] // Офіційна база законодавства України. 2016. - Режим доступу : http://zakon4.rada.gov.ua/laws/show/ 995_015.

15. Winter P. How China Is Blocking Tor [Електронний ресурс] / Philipp Winter, Stefan Lindskog. - Karlstad (Sweden) : Karlstad University, 2012. - 21 р. - Режим доступу : https:// arxiv.org/pdf/1204.0447.pdf.

16. Why is it called Tor? // The Tor Project, Inc. [Електронний pecypc]. - 2016. - Режим доступу : https://www.torproject.org/ docs/faq.html.en\#W hyCalledTor

17. Судебно-юридическая газета, 22 ноября 2016 [Електронний ресурс] / [шеф-ред. С. Пограничный]. - 2016. - Режим доступу : http://sud.ua/news/2016/11/22/97732-v-velikobritaniiprinyali-samij-zhestkij-zakon-o-slezhke?BPCTRY=1.

18. Travis A. "Snooper's charter" bill becomes law, extending UK state surveillance [Електронний ресурс] / Alan Travis // The Guardian, 29 November 2016. - Режим доступу : https:// www.theguardian.com/world/2016/nov/29/snoopers-charter-billbecomes-law-extending-uk-state-surveillance.

19. Paul R. Security expert used Tor to collect government email passwords [Електронний ресурс] / Ryan Paul // ArsTechnica, 09.10.2007. - Режим доступу : http://arstechnica.com/security/ 2007/09/security-expert-used-tor-to-collect-government-e-mailpasswords/.

Стовпец Александр,

кандидат философских наук, докторант

Южноукраинского национального педагогического университета им. К. Д. Ушинского

\section{ПЕРЕОСМЫСЛЕНИЕ МОРАЛЬНО-ЭТИЧЕСКИХ И ИНФОРМАЦИОННЫХ АСПЕКТОВ ЖИЗНИ СОЦИУМА В ФИЛОСОФСКОМ ИССЛЕДОВАНИИ ИНСТИТУТА ИНТЕЛЛЕКТУАЛЬНОЙ СОБСТВЕННОСТИ}

В статье анализируются четыре сферы социального бытия - т. н. "информационная сила", общественная мораль, публичная информация и массовая информация. Утверждается, что все они в информационно зависимом обществе довольно тесно связаны, а осмысление их взаимных корреляций и детерминаций является важным на пути исследования интеллектуальной собственности как одного из фундаментальных социальных институтов современности. Понимание информационной и этической природы интеллектуальной собственности даёт возможность сформировать более объективное представление о характере трансформации данного вида собственности в нынешних социокультурных реалиях.

Ключевые слова: интеллектуальная собственность; информация; общественная мораль; информационная зависимость; общество.

Stovpets Oleksandr,

PhD in Philosophy, Doctoral applicant, Philosophy, Sociology \& Sociocultural activities management department, South Ukrainian National Pedagogical University named after K. D. Ushynsky, associate professor of Odessa National Maritime University, Faculty of Law

\section{RECONSIDERING OF THE ETHICAL AND INFORMATIONAL DIMENSIONS OF SOCIAL LIFE WITHIN A PHILOSOPHIC ENQUIRY FOR INTELLECTUAL PROPERTY INSTITUTION}

The article analyzes four areas of social life - the so-called "information power", public morality, public information and mass-media information. It's argued that they have become closely related in the information-dependent society. Understanding of their cross correlations and mutual determinations, as well as interconnections of those categories, is an important matter on the way of Intellectual Property philosophic research, believing the IP is one of the fundamental social institutions of our time. 
Regarding the abovementioned, the purpose of this research paper is to synthesize a socio-philosophical vision of nowadays mutual determination and correlation of "information power", public morality, public information and mass-media information aspects of social reality. Then we obtain an opportunity to make appropriate extrapolation of these links and interdependencies into a social institution of Intellectual Property.

At first glance, the relationship amidst mentioned four categories together is not quite obvious, as well as their relation to the Intellectual Property institution. But it becomes clearer when we define each of those aspects.

The phenomenon of "information power" is functionally associated with the Intellectual Property institution: countries-innovators maximize their organizing (political \& legal) and technological efforts to maintain a monopoly for intellectual property protected products as long as possible. In particular that applies to the objects protected by industrial property laws (i.e. patents), and the objects of copyright (for literary works, software, other "intellectual capacious" products). On effective protection of this monopoly it may depend the whole prospects of domination of some countries in the post-industrial world. Sometimes the use of "information power" ignores the principles of public morality, leaving the ideas of humanism, equality, freedom of information exchange, free access to knowledge and technologies, and some other noble postulates declared by the governments of leading countries regularly.

In its turn Public Morality institution is essential to the substantiation of intellectual property, to the legitimization of this kind of "monopoly for knowledge" in information-dependent society. The state of public morality makes an influence upon the ideology formation inside different societies, including mental manifestations of their attitude towards the property itself, and intellectual property in particular.

The Public Information is rather capacious notion. In the context of intellectual property it is most applicable to cases where the validity of intellectual-legal monopoly expires, and the product of creative or intellectual activity goes into the category of "the public domain". If we would restrict ourselves by terminology of Ukrainian legislation about information, then we could conclude that "public information" is almost incompatible with any monopoly on information. Therefore the right to distribute the information subjected as "a matter of public interest" (i.e. public information) sometimes comes into logical conflict with intellectual property rights. And further everything will already depend on a philosophical interpretation, as any intellectual product has its value for society's growth potential, so any object of intellectual property may be considered a priori as one that is "a subject of public interest" accordingly. But here we should recall the constitutional principles of the private property inviolability, and respect to the author's exclusive rights to own, to use and to dispose with the results of his own intellectual or creative work. After all, any work must be fairly rewarded, and the intellectual work especially.

The term "mass-media information" is not the same as "public information". The mass-media info is not so much related to the content, as to the audience towards it meant to be distributed (i.e. to unlimited number of people), and depends on the means and methods of broadcasting (using various media). The social significance of the mass-media information also varies. The Intellectual Property institution "meets" the mass-media institution in communicative space. The media are able to promote intellectual property commercialization very effectively. It's obvious that the media often do a popularizing effect, a distribution function for the newly created intellectual property objects. At the same time creative \& intellectual products affect directly to the media ranking, filling their pages and diversifying their broadcasting by interesting creative production, that surely finds its audience.

The reflection of referred issues is performed within the Doctor habil. Dissertation for philosophic research named "Intellectual Property Institution at the age of Information and Postmodernity: social-philosophic view". Methodological grounds of the research are based on general scientific methods and ad hoc approaches (as particularly are dialectical and comparative-legal methods, systemic, attributive, cognitive and procedural approaches).

Selected problematic's relevance is determined by the increasing weight and significance of intellectual property at the Information age. The Intellectual Property institution has become an inalienable sociocultural attribute of post-industrial society. Thus, the comprehension of informational and ethical nature of Intellectual Property enables to create a more objective view of the transformation's character for this specific kind of property at current sociocultural realities.

Keywords: intellectual property; information; public morality; informational dependence; society.

\section{REFERENCES}

1. Stovpets, O.V. (2015), Ontological principles of intellectual property, Scientific knowledge, methodology and technology, № 1 (34), 179-186 (ukr).

2. Zobnin, A.V. (2007), Space and time in the world politics and international relations, Materials of the 4th Convention RISA, Vol. 6 , MGIMO-University, Moscow, 152 p. (rus).

3. Nye, Joseph S. (2004), Soft Power: The means to success in world politics, Public Affairs, New York, 191 p. (eng).

4. Deutsch, K. W. (1966), Nationalism and Social Communication: An Inquiry into the Foundations of Nationality, MIT Press, Cambridge (Massachusetts), 345 p. (eng).

5. Habermas, Yu. (2000), Moral consciousness and communicative action [Translat.], Nauka, St. Petersburg, 380 p. (rus).

6. Rothkopf, D. J. (1998, Spring), Cyberpolitik: The Changing Nature of Power in the Information Age, Journal of International Affairs, Vol. 51. No. 2, pp. 325-359 (eng).

7. Libicki, M. C. (1998, Spring), Information War, Information Peace, Journal of International Affairs, Vol. 51. No. 2, pp. $411-428$ (eng).

8. Froman, Michael B. G. (2015), Special 301 Report Ambassador, United States Trade Representative, Executive Office of the President of the United States, 78 p., available at: https://ustr.gov/sites/default/files/2015-Special-301-Report-FINAL.pdf

9. On protection of public morals: Law of Ukraine on November 20, 2003 p. № 1296-IV, Supreme Council of Ukraine, № 14, Art. 192 (in current the current edition of 12.09.2015)

10. Solovyov, V.S. (1988), Justification of the Good. Moral philosophy, Coll. Op.: Vol. 1, Mysl Publishing, Moscow, 479 p. (rus).

$$
\text { СХІД № } 6 \text { (146) листопад-грудень } 2016 \text { р. }
$$


11. Ilyin, I.A. (1994), On the essence of justice, Coll. Op.: Vol. 4, Russian book, Moskow, 498 p. (rus).

12. Drozhzhina, S.V. and Shirkova, I.V. (2011), Problem of interaction between law and moral values as regulators of social relations in the context of social and philosophical discourse, Gilea: Research Journal: Proceedings of (Philosophy), Vol. 47 (5), 792 p. (ukr).

13. On Access to Public Information: Law of Ukraine of 13 January 2011 r. 2939 number-VI // Supreme Council of Ukraine, № 32, Art. 314 (in current the current wording of 01.05.2015).

14. The Universal Declaration of the Human Rights in 1948 [Transl.] (2016), available at: http://zakon4.rada.gov.ua/laws/show/ 995_015

15. Winter, Philipp and Lindskog, Stefan (2012), How China Is Blocking Tor, Karlstad University, Karlstad (Sweden), 21 p., available at: https://arxiv.org/pdf/1204.0447.pdf

16. Why is it called Tor? (2016), The Tor Project, Inc., available at: https://www.torproject.org/docs/faq.html.en\#WhyCalledTor

17. Judicial and legal newspaper, November 22, 2016, available at: http://sud.ua/news/2016/11/22/97732-v-velikobritanii-prinyalisamij-zhestkij-zakon-o-slezhke?BPCTRY=1

18. Travis, Alan (2016), «Snooper's charter» bill becomes law, extending UK state surveillance The Guardian, 29 November, available at: https://www.theguardian.com/world/2016/nov/29/snoopers-charter-bill-becomes-law-extending-uk-state-surveillance

19. Paul, Ryan (2007), Security expert used Tor to collect government e-mail passwords, ArsTechnica, 09.10.2007, available at: http://arstechnica.com/security/2007/09/security-expert-used-tor-to-collect-government-e-mail-passwords/

(с) Стовпець Олександр

Надійшла до редакції 22.11.2016

УДК 37.015.31:57

ФІЛЯНІНА НЕЛЯ,

доктор філософських наук, дочент, завідувач кафедри гуманітарних наук Начіонального фармачевтичного університету, м. Харків

\section{РОЛЬ КРИТИЧНОГО МИСЛЕННЯ У ФОРМУВАННІ ЕКОЛОГІЧНОї КОМПЕТЕНТНОСТІ}

У статті досліджується потенціал компетентнісного підходу в сучасній освіті. Автор стверджує, що компетентність як базове поняття сучасної освітньої теорії та практики набуває особливої ваги в екоосвіті у формі екологічної компетентності. Екологічна компетентність належить до загальної компетентності, охоплюючи низку специфічних компетентностей, спрямованих на розв'язання особливих і нестандартних завдань. Критичне мислення є невід'ємною характеристикою екологічної компетентності, а формування критичного мислення в поєднанні 3 творчістю та інформаційною грамотністю - це основа становлення екологічної компетентності.

Ключові слова: компетентність; компетентнісний підхід в освіті; критичне мислення; інформаційна грамотність; проблемно орієнтована концепція освіти Пауло Фрейре.

Постановка проблеми. Для подолання викликів, спричинених затяжними глобальними, регіональними та локальними екологічними кризами, світова спільнота розглядає широкий спектр політичних, економічних, наукових, соціальних інструментів. Серед них важливе місце посідають екологічна освіта і виховання, яким надають великого значення практично від початку усвідомлення загроз, пов'язаних з екологічними кризами. Проте, незважаючи на значну увагу до екоосвіти з боку політиків, освітян, природоохоронців і громадських активістів, досі не вироблено консолідованого бачення фрілософських і методологічних засад та дидактичних принципів екоосвіти та формування екологічної компетентності сучасної людини.

Це $є$ однією з причин подальшої деградації навколишнього природного середовища, погіршення якост життя та здоров'я людей, а також нездатності людини адекватно реагувати на екологічні виклики, ухвалювати адекватні рішення, діяти, не завдаючи шкоди довкіллю. Розв'язання цих завдань формує стійкий суспільний запит на формування екологічної компетентності людини і громадянина, у тому числі й засобами екологічної освіти.

Аналіз досліджень і публікацій з проблеми. Дослідженню потенціалу компетентнісного підходу в освіті приділяється значна увага з боку вітчизняних та зарубіжних дослідників [7; 8; 15; 16; 18], проте одностайного розуміння, як упроваджувати такий підхід в освітню діяльність, поки що не досягнуто. Можливо, розгляд окремих складових компетентності, які пов'язані з реальними об'єктами дійсності, а також фундаментальними об'єктами освіти, дозволить з'ясувати нові спосо- 